\title{
RUSSIAN, JEWISH OR HUMAN? JEWISH MYSTICAL THOUGHT IN THE POETRY OF BULAT SHALVOVICH OKUDZHAVA
}

\author{
Katarzyna Anna Kornacka-Saręo ${ }^{1}$ \\ (Adam Mickiewicz University in Poznań)
}

\begin{abstract}
Keywords: Bulat Shalvovich Okudzhava, poetry, imagology, Jewish mysticism, Jewish philosophy of dialogue

Słowa kluczowe: Bułat Okudżawa, poezja, imagologia, mistycyzm żydowski, żydowska filozofia dialogu
\end{abstract}

\begin{abstract}
Katarzyna Anna Kornacka-Sareło, RUSSIAN, JEWISH OR HUMAN? JEWISH MYSTICAL THOUGHT IN THE POETRY OF BULAT SHALVOVICH OKUDZHAVA. "PORÓWNANIA" 2 (21), 2017, P. 197-214. ISSN 1733-165X. While looking at the literary output of Bulat Shalvovich Okudzhava from the perspective of imagology, one can see that the image of "the Other" in the poems of the Russian bard was created, paradoxically, just by this "Other", and it was not constructed by the images (imagines) intrinsically present in the consciousness of the ethnocentric "Self" or "The Same". In other words, in the case of Okudzhava's poetry, the image of "the Other" stands on the basis of some ideas of Jewish mystics and the ones of Jewish philosophers of dialogue (Martin Buber, Franz Rosenzweig and Emmanuel Lévinas). Therefore, the aim of this article was to present the motifs stemming from Jewish mysticism in the poems-songs by Okudzhava which, as it seems, influenced theological, anthropological and ethical views of the bard. The distinctive feature of Okudzhava's philosophical approach is perceiving every person, regardless of their ethnic or cultural origin, as a being responsible for themselves in the process of constituting themselves in their humanity. The same person is also responsible for other people, for the world of nature, and even for an impersonal and non-anthropomorphic godhead who does not intervene in human affairs. Therefore, Okudzhava - similarly to Jewish mystics - regards the human being as a co-creator of reality, obliged to perform ethically positive acts and respect an old Kabbalistic postulate tikkun ha-olam - "to mend the world".
\end{abstract}

Abstrakt: Katarzyna Anna Kornacka-Sareło, ROSYJSKIE, ŻYDOWSKIE CZY LUDZKIE? ŻYDOWSKA MYŚL MISTYCZNA W POEZJI BUŁATA SZAŁWOWICZA OKUDŻAWY. „PORÓWNANIA” 2 (21), 2017, S. 197-214. ISSN 1733-165X. Spoglądając na literacki dorobek Bułata Szałwowicza Okudżawy z perspektywy imagologii, można dostrzec, że

1 E-mail: kat.kor@amu.edu.pl 
wizerunek Innego w poezji rosyjskiego barda został ukształtowany - paradoksalnie - właśnie przez Innego, nie zaś przez obrazy (imagines) utrwalone w kulturowej świadomości etnicznie Tożsamego. Innymi słowy - w przypadku Okudżawy - stworzony przez poetę portret Innego powstał dzięki pewnym ideom żydowskich mistyków oraz doktrynie żydowskich filozofów dialogu (Martina Bubera, Franza Rosenzweiga, Emmanuela Lévinasa). Tak więc celem autorki artykułu było ukazanie w pieśniach Okudżawy motywów pochodzących z żydowskiej myśli mistycznej, która, jak się wydaje, wywarła znaczący wpływ na teologiczne, antropologiczne i etyczne poglądy rosyjskiego barda. Charakterystyczne dla nich jest postrzeganie każdego człowieka - niezależnie od jego etnicznego pochodzenia - jako bytu odpowiedzialnego za siebie samego w procesie konstytuowania się w swoim człowieczeństwie oraz definiowania własnej podmiotowości. Ten sam człowiek, na co wskazuje interpretacja utworów rosyjskiego poety, powinien być również odpowiedzialny za innych ludzi, świat natury, a nawet za nieosobowe i nieantropomorficzne bóstwo: obojętne wobec ziemskiego dominium. Okudżawa - podobnie jak żydowscy mistycy i żydowscy filozofowie dialogu - postrzega zatem człowieka jako współtwórcę rzeczywistości, zobligowanego do realizacji aktów pozytywnych w porządku etycznym, podejmowanych w celu „naprawy świata”, określanej przez kabalistów jako tikkun ha-olam.

\section{Introduction}

One of the imagology theorists, "Joep" - Joseph Theodoor Leerssen, wrote in his well-known article, "Imagology: History and Method", that "the tendency to attribute specific characteristics or even characters to different societies, races or 'nations' is very old and very widespread. The default value of human contacts with different cultures seems to have been ethnocentric, in that anything which deviated from the well-known domestic patterns is 'Othered' as an oddity, an anomaly, a singularity" (Leerssen 2007: 17). In fact, some empirical and every-day observations seem to justify the Leerssen's statements. Thus, it can be said that, usually, we look at different "Others", bearing some stereotypes in our minds, and, very often, we are not able to change our fixed and stable world-views. That is why, at least in Poland, Germans are usually perceived as a well-organized nation, Jews are seen as mean, whereas the Polish or Russian people are supposed to be alcohol-addicted.

Normally, we take for granted these national or racial stereotypes, not even trying to see "the Other" or "the Others" from a new perspective. Thus, our mental constructs seem to have been established previously, and they are very much entrenched. Such stereotypical "brain-matrices" can generate serious problems as far as our communication possibilities are concerned. For example, it is sometimes very difficult or just impossible to explain to a - typical and not highly educated - Israeli man or woman that a lot of people in Poland do not demonstrate anti-Semitic attitudes. Such an explanation remains extremely difficult, although in the Garden of Yad Vashem (The World Holocaust Remembrance Center) in Jerusalem, there are many trees dedicated to "the Righteous Among the Nations", and most of these "righteous" are actually people of Polish origin. On the other hand, as we know, it is sometimes very difficult to convince a - "typical" and sometimes even a highly 
educated, Polish man or woman - that Jews do not "rule the world" so that they can achieve the highest economical profits or that not all Jews are rich.

Indeed, "the tendency to attribute specific characteristics or even characters to different societies, races or 'nations'", mentioned by Leerssen, is expressed in numerous literary works of art. At this point, for example, an almost unknown poem written by Vladimir Semyonovich Vysotskii comes to mind. Vysotskii was one of the most popular bards and actors in the Soviet Union of the post-war period. The poem's title is "Song of an Antisemite", and it was written in 1964. In fact, the text can be properly named as a literary satire. The lyrical "I" - seems to be identifying himself exactly with a "typical" representative of the Russian society. He ironically presents a commonly accepted, stereotypical and dangerously xenophobic narrative about an ethnic "Other". In this case, it is a narrative about Jews living in the USSR:

„Им кровушки надо - они по запарке
Замучили, гады, слона в зоопарке!
Украли, я знаю, они у народа
Весь хлеб урожая минувшего года!

По Курской, Казанской железной дороге

Построили дачи - живут там как боги...

На все я готов - на разбой и насилье,-

И бью я жидов - и спасаю Россию!" (Vysotskii, electronic source)

(Without more blood they simply can't do/ They tortured an elephant right in a zoo/ Against our people committed high treason/ And stole all the crops of the previous season/ Along major highways they grabbed all the lots/ Built luxury dachas and live there like gods/ I'll maim and I'll burn, just to make them pay dues/ To save our country, I club dirty Jews.) $)^{2}$

As we can read, Jews as such - according to the Russian mental stereotype - are murderers, beasts and thieves. Besides, they are definitely too rich, especially in comparison with ethnically Russian citizens. Consequently, it becomes a patriotic duty or even a moral obligation to kill the Jews and "save" the country in such a way. Of course, the Russian anti-Semitism, flourishing in the Soviet Union in the times of the Communist regime and also nowadays, is a commonly known phenomenon. In Russia, Jews have been regarded as strangers, dangerous, different and odd in spite of their great merits and significant achievements in the field of the Russian culture, which is not a mystery to anyone. Nevertheless, these merits and achievements could not - and still cannot - be compared with the alleged Jewish

2 The English translation of Vysotskii's poem by B. Gendelev: The Song of an antisemite, http:/ /www. kulichki.com/vv/eng/songs/gendelev.html\#song_of_an_antisemite. 
cruelty and wickedness noticeable by Russian nationalists who strongly believe in a stereotypical image of the Jew: the image which remains intrinsically present in their ethnocentric minds, as they are the minds of the people dwelling in their ethnocentric caves. Certainly, perceiving all Russians as a nation with strong anti-Semitic prejudices would be seriously misleading, too. Moreover, such an approach would cause the creation of an incorrect, false and absolutely dishonest "image" of Russian men and women expressing their criticism of anti-Semitism in the public sphere. It is also obvious that not all ethnically Russian citizens must necessarily be nationalists or xenophobes. Similarly, it is quite clear that some Russians remain open to "the meaning" of "the Other", as they appreciate and respect foreign cultures and want to learn and experience various culture codes.

Thus, I did not find either unusual or striking - albeit very interesting - the fact that many concepts coming from the Jewish mystical thought and the Jewish philosophy of dialogue can be revealed in the poetical output by Bulat Shalvovich Okudzhava, a Russian poet and bard, one of the first creators of the so called author's-song. ${ }^{3}$ Both Okudzhava and his poetry, definitely belong to the area of the Russian culture after the Second World War. The bard was a Russian native speaker, although his father was Georgian and his mother's ethnic origin was Armenian. In other words, the poet was brought up as a Russian citizen and even as a Russian patriot. He served - as a volunteer - in the Russian army, during the war, then he studied Russian philology in Tbilisi, and later he taught Russian in a village school. However, as an adult, Okudzhava had very close friends of Jewish origin: two poets, Iurii Davidovich Levitanskii and David Samoilov (David Samuilovich Kaufman), as well as a great music composer, Issac Schwartz ${ }^{5}$. As it seems to me, the Jewish friends presented to Okudzhava some ideas stemming from the Jewish mystical thought, especially from the Kabbalistcic Lurianic system, i.e. the philosophical set of doctrines created by Isaac Luria known as "the Holy Ari", ha-ari-ha-kadosh, from Safed in Galilee. ${ }^{6}$ The foundation myth of the Safed school is the tzimtzum concept, according to which the infinite and endless godhead, En-Sof Or - the endless light or a kind of endless, infinite energy, during the first stage of the act of creation of finite beings had to contract and negate Himself/ Herself to make, within itself, an emp-

3 For a detailed biography of Bulat Shalvovich Okudzhava in English, see: Pushkova, electronic source. In Polish, see: Urban-Podolan.

4 David Samuilovich Kaufman (David Samoilov), born in 1920, was a Russian poet and interpreter of Jewish origin. He graduated from the Moscow Institute of Philosophy, Literature and History (Moskovskii Institut Filosofii, Literatury i Istorii - MIFLI). He spent most of his life in Pärnu, a city in southwestern Estonia, and died in Tallinn, the capital city of Estonia, in 1990 (Dmitriev 5-12).

5 The only biographies of Issac Schwartz (1923-2009) both in English and in Polish, which I fave found so far, are available on-line. In English, see: http://russia-ic.com/people/general/s/378. In Polish, see: Chosiński, electronic source.

6 For a detailed history of the mystical school in Safed and Isaac Luria's biography, see: Fine. 
ty space, ${ }^{7}$ into which "this world" and some other "worlds" have been emanated. En-Sof is sometimes identified with Ayin: denoting a Divine Nothingness, deprived of (almost) any attributes. ${ }^{8}$ Thus, nothing can be said about the Creator of the Universe-the holy Emanator, as the Divine manifests itself to the world in the form of ten sephirot, during a constant emanation process: the process called atzilut. ${ }^{9}$ In other words, we do not know if the absolute being is strong or weak, merciful or cruel, helpful or dangerous, good or bad. But we do know that during the second stage of the creation of the physical universe, a pre-cosmic catastrophe took place. Thus, the harmony of the light (energy) was dramatically disturbed, which, generally speaking, resulted in the destruction of both the world(s) and the godhead. Consequently, the divine substance has been scattered all around us in the form of nitzotzot, numerous and countless "holy sparks". The sparks of holiness exist also within ourselves - human beings, but we, usually, are not aware of this fact. Nevertheless, it is our moral task and obligation to restore the primordial order by performing the tikkun ha-olam postulate ${ }^{10}$. In other words, human beings - not the godhead - have to mend the broken world by performing ethically good acts, transforming chaos into cosmos, and helping the powerless and broken God, deprived of His/Her male - female unity, to come back to the "celestial", spiritual, and metaphysical sphere from an unplanned Exile to the earthly, mundane and imperfect dominion.

Okudzhava, the Russian poet of the twentieth century, showed these Jewish philosophical concepts in his poems-songs, perceiving what-was-strange, whatwas-odd, and what-was-unknown to him as a valuable gift, thanks to which he could build and create his own philosophy of life, God, and the human being. The

7 As Gershom Scholem writes, tzimtzum means "originally 'concenration' or 'contraction', but if used in the Kabbalistic parlance it is best translated by 'withdrawal' or 'retreat'" (Scholem 260).

8 "AYIN, NOTHINGNESS, is more existent than all the being of the world. But since it is simple, and every simple thing is complex compared with its simplicity, it is called Ayin. The inner power is called Ayin because thought does not grasp it, nor reflection. Concerning this, Job said, 'Wisdom comes into being out of ayin'" (Matt 66).

9 "The difficulty lies precisely in the fact that the emanation of the Sephirot is conceived as a process which takes place in God and which at the same time enables to perceive God. In the emanation something which belongs to the Divine is quickened and breaks through the closed shell of His hidden Self. This something is God's creative power, which dose not reside only in the finite universe of creation, although of course there, too, it is immanent and even perceptible" (Scholem 209).

10 "The Kabbalah proposed a new creation narrative, one that gave new meaning to God's presence in the world and man's role there, while formulating a new language that explained the ongoing relation between the infinite and the finite and between God and man. The new creation narrative encompassed the dialectical concepts of overflowing, infinite bounty (shefa) and finite contraction (tzimtzum); the infinite expansion and the limiting withdrawal; and the outcome of this tension: breakage (shevirah) or "breaking of the vessels" (shevirat ha-keilim) and restoration (tikkun). All these concepts (shefa; tzimtzum; shevirah, shevirat ha-keilim) were part of the divine process of creation that preceded the creation of our "broken" world, a world whose fundamental essence is in exile. Only the last concept, that of tikkun - restoration of the broken world - was entrusted to the hands and mind of human beings" (Elior, electronic source). 
first of Okudzhava's poems, which I would like to discuss in this context, is a song written to the memory of Vladimir Semyonovich Vysotskii, mentioned above, who died as a young man, at the age of 42 . He was said to be addicted to drugs and alcohol. He also suffered from a serious heart disease. Vysotskii lived, so to speak, very quickly: as if he knew well that he is not allowed to waste his precious time, regardless of any circumstances. Nevertheless, he was popular, famous, admired and loved in the Soviet Russia for his politically courageous songs, and for a special and unique style of singing. ${ }^{11}$ His premature and unexpected death influenced Okudzhava so strongly that he wrote a moving tribute to Volodia:
О Володе Высоцком я песню придумать решил:
Вот еще одному не вернуться домой из похода.
Говорят, что грешил, что не к сроку свечу
затушил
Как умел, так и жил,
а безгрешных не знает Природа [ . . . . (Okuzdhava, electronic source 1).

(I decided to come up with a song about Volodia Vysotskii: / Look, one more man will not come back home from the march. / They say that he was a sinner, that too early/ he put his candle out... / He lived as he could, / and, [besides], the Nature does not know the sinless [. . .]. $)^{12}$

The most important message of the text is the postulate of the acceptance of each man, even a sinner. It is motivated by the fact that every human being is prone to become sinful, but this evident fact should not imply a severe judgment of others. People are different, Okudzhava says. They are sometimes weak and unreasonable: they live as they can, not being able to struggle against some evil forces ruling the world. These forces are perceived as a constituent of reality. Besides, man's way of life, the human pochod in the bard's poem, is not always straight: difficulties can cause the fall of man who is not necessarily guilty but simply powerless. The sinfulness is a part of human existence, being very similar to holiness. ${ }^{13}$ Then, the only

11 "Vysotsky's songs are like roles from some unwritten plays. Plays with such roles would probably be written in some time, but he did not want to and could not wait. So he made up those roles and was both the stage-director and performer himself. Performing his songs-roles with unique characters, non-invented conflicts and precisely developed plots, he was raving and stormy, his husky voice making audience thrill. It seemed impossible to sing and even to breathe under such a nervestrain, but he did." (Ivanova, Manykin, electronic source). In Polish, see: Podgórzec and Vlady.

12 All of the English translations of Bulat Okudzhava's poems in this article are mine, unless indicated otherwise.

13 "Where we find man's deepest fall, there also do we find his most sublime ascent. [. . .] Is it possible to accept man in view of his limitless ability for evil? Is it possible to reject him, witnessing his equally limitless ability for good?" (Berkovits 2007: 331). 
obligation of man is to choose and act according to his or her free will given to man by the Creator-"the One". And that is why, also Okudzhava's Jewish friend, Iurii Davidovich Levitanskii puts it out quite clearly:

\author{
Каждый выбирает для себя \\ женщину, религию, дорогу. \\ Дьяволу служить или пророку - \\ каждый выбирает для себя [. . .]. (Levitanskii, electronic source). ${ }^{14}$
}

(Everyone chooses for himself / a woman, a religion, a way. / To support a devil or a prophet - /Everyone chooses for himself.)

Thus, in both Okudzhava's song and in the verses by Levitanskii, man is seen as the only author of good and evil. He is obliged to make independent moral choices, being responsible for his own future because, as a Jewish philosopher, Eliezer Berkovits - inspired by the thought of the Jewish mystics of older generations - explains, people are not "puppets" dangling in the hands of God or godhead, but they have to change the world into a better place, performing the tikkun ha-olam postulate and restoring the primordial order of the universe. ${ }^{15}$ Certainly, human beings can also transform the world into a real hell, if they "serve a devil", which, unfortunately, happens quite often, and which is empirically demonstrated from time to time. ${ }^{16}$

The motif of total acceptance of "the Other" who is absolutely different from "I" - being the subject of moral choices - appears also in one of the most famous poems by Okudzhava, entitled "Molitva" (The prayer), also known by the title "Molitva Fransua Viiona" (The prayer of François Villon), written by Okudzhava in 1963.

\footnotetext{
Пока земля еще вертится,

Пока еще ярок свет,

Господи, дай же ты каждому,

Чего у него нет:

Мудрому дай голову,
}

14 The English translation of the poem by Levitanskii is mine.

15 "As a result, as Gershom Sholem writes, 'The restoration of the ideal order, which forms the original aim of creation, is also the secret purpose of existence. Salvation actually means nothing but the restitution, re-interpretation of the original whole, or tikkun. In effect, people are responsible for restoring the harmony and perfection of the world by recapturing the spilled divine light through good deeds and religious observance'"' (Baigell: 346).

16 "We find ourselves not in a universe of puppets, dangling from the strings of the Almighty and obeying every one of his commands, but instead in a universe in which freedom makes the deed possible. No doubt, God took a risk with creation by granting it consciousness and free decision. Such freedom may be misused at any time, or it would not deserve its name" (Berkovits 2004: 83). 
Трусливому дай коня,

Дай счастливому денег . . .

И не забудь про меня.

Пока земля еще вертится -

Господи, твоя власть!

Дай рвущемуся к власти

Навластвоваться всласть,

Дай передышку щедрому,

Хоть до исхода дня.

Каину дай раскаяние . . .

И не забудь про меня

Я знаю: ты все умеешь,

Я верую в мудрость твою,

Как верит солдат убитый,

Что он проживает в раю,

Как верит каждое ухо

Тихим речам твоим,

Как веруем и мы сами,

Не ведая, что творим! [. . .] (Okudzhava 226).

(As long as the Earth keeps turning, / as long as the light keeps shining,/Oh, Lord, give to each man / what he lacks: /Give an [even wiser] head to a wise one,/Give a horse to a coward,/give [more money] to a wealthy one ... / And do not forget about me./ As long as the Earth keeps turning - /Oh, Lord, [it is in] your power!/ Give as much power as you can/to someone who loves to be powerful,/Give a rest to a generous one, at least, till the end of the day./Give repentance to Cain,/and do not forget about me./I know: you are able to do everything, / I believe in your wisdom,/as a killed soldier believes / That he is still living in the Paradise,/As every [human] ear believes/That it hears your so silent words,/and as we do believe,/Not knowing, what we do.)

Although the addressee of this song-prayer is - at first sight-God, the Absolute is far less important than other elements of the world depicted in the poem. For example, one can say much about the lyrical " $\mathrm{I}$ " in Okudzhava's song. The "I" seems to be an old and mature man having vast anthropological knowledge. He is aware that people differ from one other to a very great extent, as far as their attitudes and personalities are concerned. Some of them are wise, which implies that others are less intelligent; some of them are happy and wealthy, others are less fortunate; some are brave, but others can be characterized as cowards; some are generous, whereas others can be considered mean. The poet-philosopher, who can be identified here 
with the lyrical subject of "Molitva," agrees with "the otherness" of others, regardless of their virtues or imperfections, not taking into consideration their ethnic origin at all. ${ }^{17} \mathrm{He}$ is praying for their well-being and happiness depending on different people's life goals, preferences and choices already made in their lives. In other words, Okudzhava-or the poem's lyrical subject-accepts all people, although their behaviors are not necessarily understandable to him, for the "Other" cannot be "understood" or "comprehended" in any way. What is especially important is that the lyrical "I" does not want to change anybody. The world around him is as it is, and it is as it should be. The people surrounding the poet - the "I" - are as they are, and they should not only be tolerated, but totally accepted..$^{18}$ Even the sinful Cain deserves some acceptance and some help from the part of the "I." That is why, the speaking " I" is praying for the biblical fratricide as well.

At the same time, the lyrical subject consciously, it seems, tries to distance himself from other people: he can be compared with no one, and he is a unique entity. ${ }^{19}$ Therefore, he feels that he is a completely separate being, transcending "otherness" and accepting also his own Ipseity, being expressed, in his case, by the lack of his own desires and personal needs. Such a separation is a fundamental condition of every social interrelation postulated by Jewish dialogical thought. It is obvious that a real dialogue or a mere conversation can exist only between disjoined and separate beings. Otherwise, only monologues could be performed, but such soliloquia influence no one and nothing: they are not able to mend the world. ${ }^{20}$ That is why they are meaningless. Therefore, man has to create a positive relation between himself and other people and between himself and the rest of the nature. This is the only way for him to empower himself in his humanity and constitute his own personality in its entirety. Simultaneously, this life-attitude is perceived by Okudzhava as a true destination of man, who takes part in the process of the creation of reality. Thus, the poem's title, "Molitva," is, to some extent, misleading. Although the lyrical " $\mathrm{I}$ " is

17 Emil Fackenheim, one of the most famous Jewish philosophers of modern times, while presenting the views by Franz Rosenzweig, writes, "The human 'thou' addressed in love is always particular, indeed, singled out. There is a falsely universal 'all-love' which loves everyone and no one" (Fackenheim 77).

18 "Genuine conversation, and therefore actual fulfillment of relation between men, means acceptance of otherness" (Buber 13).

$19^{\prime \prime}$ In this way we reach the insight that the principle of human life is not simple but twofold, being built up in a twofold movement which is of such kind that the one movement is the presupposition of the other. I propose to call the first movement 'the primal setting at a distance' and the second 'entering into relation.' That the first movement is the presupposition of the other is plain from the fact that one can enter into relation only with a being which has been set at a distance, more precisely, has become an independent opposite. And it is only for man that an independent opposite exists" (Buber 4).

20 The moral commandment and moral obligation to mend and heal the world - tikkun ha-olam - is firmly rooted in the Jewish tradition, especially in the so-called Kabbalistic Judaism. On this question, see, for example: Fackenheim 253. 
praying to God, he seems not to believe, in fact, in any potentially redemptive acts made by the Lord of the universe, as the godhead does not intervene in human matters, and God's voice is "very silent" in the world, which He created and which is still being created by Him. People, however, believe in the existence of the Transcendence, because they just want and have to believe in a supernatural force. It can be explained by their need for "metaphysics", justifying people's earthly existence and giving them hope for some after-death future. The lyrical subject identifies himself with others: he also wants to have some faith in God, but, simultaneously, he realizes that his belief is an illusion. It is obvious that the "killed soldier" in the poem cannot believe that he is still living: he was killed which implies being dead. Similarly, a wise and powerful God, if He truly existed and if He possessed such attributes as wisdom, powerfulness and strength, should not allow anybody to kill another man: he would not have allowed Cain to murder Abel and he would not have let any soldiers be killed. Thus, also Okudzhava's hero - the young soldier - would not have been killed, if God was a truly merciful and powerful being.

The poet's world-view - so similar to Kabbalistic and "dialogical" ethical concepts - was expressed by the Russian bard in the song entitled "Gruzinskaia Pesnia" (A Georgian song), although this very poem could also be named "Evreskaia Pesnia" (A Jewish song). Unfortunately, Okudzhava - even if he really wanted to - was not able to give such a title to his poem for political reasons: there were strong anti-Semitic movements in the Soviet Union at that time. However, as he confessed later, "Gruzinskaia Pesnia" is, generally speaking, not an exclusively Georgian song, apart from some elements of the Georgian folklore in the poem's symbolic realm (Urban-Podolan 81). And, even if the bard did not explain it himself, it is rather evident that some Jewish mystical motifs appear-quite clearly -in this poem. Besides, its meaning seems to resonate in some universal way:

\footnotetext{
Виноградную косточку в теплую землю зарою,

И лозу поцелую и спелые гроздья сорву,

И друзей созову, на любовь свое сердце настрою.

А иначе зачем на земле этой вечной живу?
}

\section{Собирайтесь-ка гости мои на мое угощенье,}

Говорите мне прямо в глаза чем пред вами слыву,

Царь небесный пошлет мне прощение за прегрешенья.

А иначе зачем на земле этой вечной живу? [. . .] (Okudzhava 258, 260).

(I will plant a grape seed in the warm soil,/and I will kiss the vine twig, and I will pick a ripe grape cluster, /and I will invite my friends, I will attune my heart to love./Otherwise, what am I living on this eternal earth for?/Meet together and stay in here, my guests,/[Look at me]: straight in the eye, telling me who I am to you./ 
The heavenly Tsar will absolve my sins. / And, otherwise, what am I living on this eternal earth for?)

Thus, the biblical commandment to care about nature was presented by the Russian poet as an image of a man planting a grape seed and kissing a vine twig. In such a way, the lyrical subject appreciates the miracle of life and seems to contribute to the divine creation process. "Gruzinskaia Pesnia" is also one of Okudzhava's poems in which he speaks openly about his friendship and love toward other people. He is ready to get involved in a relation called "a meeting," in the Buberian sense-for, as Martin Buber says, "human life and humanity come into being in genuine meeting" (Buber 14). Such true and intensive meetings, in Okudzhava's understanding of the term, mean to become open even to some critical opinions expressed by his "friends" - the people resembling the subject of moral acts, and sharing with him certain values, opinions and a general world-view. Friends are admired as the dearest visitors. They are warmly invited to the subject's house - to his inner life, regardless of what they are going to say. ${ }^{21}$ Thus, the people around us have a right to judge our acts, which can lead to our self-improvement. ${ }^{22}$ At the same time, Okudzhava postulates a kind of deification of man, manifested by man's power to judge others, and, simultaneously, the poet perceives the feelings of friendship and love as holy, and as the only values that constitute the foundation for human existence (Urban-Podolan 81). Certainly, in this context, the religion confessed by the poem's lyrical "I" cannot be defined as "a religion of fear": the subject is, in fact, not afraid of God's punishment. On the contrary, he is waiting for God's absolution. It does not mean, however, that the poet disrespects the Absolute: he believes deeply in the cathartic power of teshuvah - return - enabling the possibility of coming back to "the way of the righteous", thanks to his or her own, independent and autonomic will to be obedient to God's voice and to His commandments. For, as Abraham Joshua Heschel points out, "The Hebrew word for repentance, teshuvah, means return. Yet it also means answer. The return to God is an answer to Him. For God is not silent" (Heschel 141). Nonetheless, Okudzhava's poetry is far less optimistic: unfortunately, it is not easy to hear God and listen to Him, as His words are not loud or clear. Perhaps what man can really hear is only a distant echo of the voice of God. The absolute being - the godhead of the Jewish mystics - remains neither above nor below, dwelling in His far-away dominion.

21 "The relation with the Other, or Conversation, is a non-allergic relation, an ethical relation; but inasmuch as it is welcomed this conversation is a teaching [enseignement]. Teaching is not reducible to maieutics; it comes from the exterior and brings me more than I contain" (Lévinas 51).

22 "Man wishes to be confirmed in his being by man, and wishes to have a presence in the being of the other. The human person needs confirmation because man as man needs it" (Buber 16). 


\section{Okudzhava's ethical radicalism}

One of the few Polish scholars working in the field of Jewish studies, Professor Tomasz Sikora, evaluated very negatively both Martin Buber and Emmanuel Lévinas. In the "Introduction" to the Polish translation of Oskar Goldberg's work, The Reality of the Hebrews, he wrote: "My understanding of Hebraism and Judaism [. . . ] was never dominated by either Martin Buber, imitating Ferdinand Ebner, pitifully superficial and pathetic, or by Emmanuel Lévinas, a primitive épigone reducing Judaism only to an ethical experience" (Sikora XCII). Theoretically, one can agree with Sikora. It is true that both Buber and Lévinas tried to show to the Western world the concepts and ideas originally worked out by Jewish mystics such as Abraham ben Samuel Abulafia, Isaak Luria, Moses ben Jacob Cordovero, Israel Ba'al Shem Tov or Nachman of Breslov (Bratslav). What is more, indeed, the modern philosophers can be perceived as "the épigones" of Jewish Kabbalists and Hasidic thinkers. Nevertheless, the works by Buber, Rosenzweig or Lévinas, written in German and French, strongly influenced the perception of reality among many circles of the intellectuals born in the so-called goy communities, including Bulat Okudzhava. However, it is striking that no one in Russia or in Central Europe would dare accuse Okudzhava of being an épigone of someone else or of being pathetic, although there are some poems in which his philosophical views can be defined as "ethically radical."

Thus, it is just Okudzhava who obviously shares the postulates of the aforementioned Jewish "dialogical" thinkers, seeing human life as a moral challenge. He regards man as a being totally embroiled in ethics and obliged to make moral choices all the time. Perhaps the rigorous philosophical message, which can be revealed from numerous poems by Okudzhava, is sometimes not noticeable because of the specific vocal performance of his songs. It seems unbelievable, when we listen to the Russian bard or when we watch Okudzhava's concerts, that this calm and nice man, singing his poems in a silent and soft voice, would like to change someone or something. However, the words of his songs, if understood properly, can be read and denoted as ethical manifestos. One such poem, to be sure, is Pesenka ob otkrytoi dveri (The song about an open door):

Когда метель кричит, как зверь-

Протяжно и сердито,

Не запирайте вашу дверь,

Пусть будет дверь открыта.

И если ляжет дальний путь

Нелегкий путь, представьте,

Дверь не забудьте распахнуть,

Открытой дверь оставьте. 
И, уходя в ночной тиши,

Без лишних слов решайте:

Огонь сосны с огнем души

В печи перемешайте.

Пусть будет теплою стена

И мягкою-скамейка ...

Дверям закрытым-грош цена,

Замку цена-копейка! (Okudzhava 150).

(Whenever a snowstorm roars like an animal - / protractedly and severely / Do not forget to open the door, / Leave the door open. / And if a long way is waiting for you. / An uneasy way, imagine,/ Do not forget to open the door,/ Leave the door open./ And leaving home in the night's silence,/ Without any empty words make a decision:/ The flame of pine with the flame of soul/ Mix in the furnace. / May the wall be warm, / And may the bench be soft... / The price of the locked door is a penny, / And a lock does cost a penny.)

The poetical image of the door, which should remain open to others, corresponds well with the motif of invitation to the house of feasting, occurring in "Gruzinskaia Pesnia" (A Georgian song). It can even be said that a hospitality motif can be found in both songs. Nevertheless, the true message of "Pesenka ob otkrytoi dveri" sounds much stronger from an ethical point of view. This time, the lyrical " $\mathrm{I}$ " is not talking about himself being in agreement with God, people and nature, but the " $\mathrm{I}$ " orders the poem's readers - the song's listeners - to keep to the rules categorically established. In short, Okudzhava seems to demand a great deal from a regular man whose own life situation is very unstable and difficult. This man does not know what his own destiny will be. Besides, the world around him is hostile, dangerous and dark. But, regardless of any obstacles and personal problems, the man is obliged to leave the door of his house open, having in mind the needs of another person. The door should be open for a stranger, even to a poor and an unhappy one-to someone in a worse situation than we are, as, according to the poet, this "someone" or this "Other" needs more help than we do. Certainly, the metaphor of the open door signifies our general attitude toward other people who should be treated by us better than we treat ourselves. Thus, Okudzhava's ethical postulate seems to be very radical and severe: similarly to the views expressed by Jewish Kabbalistic thinkers. The poet says that we should not consider our personal problems and disasters. In other words, we should not be focused, egoistically, on our own happiness, well-being or comfort. On the contrary, we must give happiness and be good to others, which, unavoidably, leads to a kind of nullification of the subject of moral acts. And, again, the words of the poem by Okudzhava correspond quite clearly to the Jewish dialogical thought, especially to its most radical version presented by Lévinas: 
"The being that presents himself in the face comes from a dimension of height, a dimension of transcendence whereby he can present himself as a stranger without opposing me as obstacle or enemy. More, for my position as I consists in being able to respond to this essential destitution of the Other, finding resources for myself. The Other who dominates me in his transcendence is thus the stranger, the widow, and the orphan, to whom I am obligated" (Lévinas 215).

Therefore, both Okudzhava and Lévinas, express their concern and their worries about those who are the weakest in the society. Additionally, their "mystical atheism" implies the negation of the possibility of any supernatural help which could be obtained from a powerful and omnipotent God. What is more, both thinkers seem to emphasize that it is not the Absolute who is responsible for the moral order in the universe, but it is man who is totally responsible for others as well as for the whole world. This responsibility is, so to speak, non-negotiable. Man can be called a human being only if he is able recognize and accept this obligation. Otherwise, his own existence remains unjustified and meaningless.

A similarly strong ethical message can be revealed in Okudzhava's song "Pesenka o moiei zhizni" (The song about my life), although the interpretation of this poem is an uneasy task. Writing this song, the Russian bard used not only colloquial words, ${ }^{23}$ but also relatively complicated syntactical structures: the poem consists of many elliptic sentences which can make it unclear:
А как первая любовь она сердце жжёт,
а вторая любовь она к первой льнёт,
ну, а третья любовь ключ дрожит в замке,
ключ дрожит в замке, чемодан в руке.
А как первая война да ничья вина,
а вторая война чья-нибудь вина,
а так третья война лишь моя вина,
а моя вина она всем видна.
А как первый обман на заре туман,
а второй обман закачался пьян,
а как третий обман он ночи темней,
он ночи темней, он войны страшней (Okudzhava, electronic source 2).

(And, as the first love-it is burning one's heart, / And, as the second love-it is cleaving to the first one, / So the third love - the key is trembling in the lock,/ The key is trembling in the lock, and there is a suitcase in one's hand./ And, as the first war - yes, [it is] no one's fault,/ and, as the second war - [it is] someone's

23 For example, "ну" (пи), “пьян" (p'ian) instead of "пьяный" (p'ianyi). 
fault, / and, as the third war - [it is] only my fault,/ and my fault is seen by everyone./ And, as the first lie-mist at dawn,/ and, as the second lie-a drunk man has swayed, /and, as the third lie - [it is] darker than night,/ [it is] darker than night, it is more terrible than a war.)

At first sight - from a philosophical point of view - this song is one of the most "existentialist" poems written by Okudzhava. The lyrical subject seems to be alienated, frustrated and even depressed. His feelings must have been hurt many times and his sufferings must have caused much pain to him. He fell in love several times, and several times he was deceived, reacting very emotionally to his misfortunes. Nevertheless, he does not blame anyone for that. Instead, he seems to understand well that he is not able to change anything as far as his personal situation is concerned. He also knows that there are different kinds of feelings related to love. Besides, he is conscious of the fact that the world that influences him is not perfect, and that people are not always good and honest. Hence, the only solution for man is just to come to terms with what is painful to him. Not only one "night" must be experienced by someone, not just one "war" has to be survived in every man's usual existence, and not one "lie" must be overcome by us, as if it were a serious illness.

However, the private or inner feelings of the lyrical subject in Okudzhava's poem does not constitute, in fact, the poem's true and deepest meaning, which can be revealed in the song's second strophe, in the two following lines: a tak tret'ia voina lish' moia vina, / a moia vina ona vsem vidna. The message expressed by these words sounds very radical. According to the poet, every one of us is responsible for the peace and tranquility among the people. Then everyone's behaviors and actions should be positive in an ethical order. We are not allowed to harm others, for our crimes or lies and frauds (obmany) can painfully hurt our neighbor: "the stranger, the widow or the orphan." Otherwise, we create evil and disaster, and we bring evil and disaster to the world. It is, of course, in our power because we are absolutely independent beings who may act according to the commands of our free will. ${ }^{24}$ At the same time, other people have the right to become our judges assessing our morality. But, on the other hand, we do not have the right to assess others, as, in the Kabbalistic thought, we are "asymmetrically" responsible for the well-being of the others, who - on the contrary - do not have any obligations towards us.

24 "By the will alone man becomes the most destructive of all beings. This is our predicament: our power may become our undoing. We stand on a razor's edge. It is so easy to hurt, to destroy, to insult, to kill. Giving birth to one child is a mystery; bringing death to millions is but a skill. It is not quite within the power of the human will to generate life; it is quite within the power of the will to destroy life" (Heschel 286). 


\section{Conclusion}

Looking at Okudzhava's literary output from the perspective of imagology one can clearly see that the image of "the Other" in the poems of the Russian poet was created, paradoxically, just by this "Other", and it was not created by the images (imagines) intrinsically present in the consciousness of the ethnocentric "Self" or "the Same". In other words, the image of "the Other" was built on the basis of the concepts worked out by "the Other": in Okudzhava's poetry case, the image of "the Other" stands on the basis of the ideas of Jewish mystics and Jewish philosophers of dialogue, as I dare to interpret his poetry. What is more: the Russian poet seems to universalize every kind of "otherness", commanding respect for all people, who, he says, deserve the right to fully exercise their autonomy. Therefore, Okudzhava presents in his poetry neither the Russian - anti-Semitic - stereotypes, nor the Jewish ethnocentric stereotypes, having their roots in the so called normative Judaism and concerning an idealized image of Jews regarded as "God's Chosen Nation".

On the contrary, Okudzhava reaches for the universalizing Kabbalistic thought and for its contemporary, dialogical kind, understood by me as a set of ideas that can be found in the theories by Martin Buber, Franz Rosenzweig and Emmanuel Lévinas. For, the distinctive feature of these philosophers' concepts is perceiving every man, regardless of his or her ethnic and cultural origin, as a being who is responsible for himself in the process of constituting himself/ herself in his or her humanity. According to both Jewish mystics and philosophers - as well as according to the Russian poet - the man is also responsible for other people, for the whole world, and even for the well-being of the godhead: not intervening arbitrarily with the destiny of what-has-been-created. At the same time, similarly to Jewish Kabbalists and philosophers, Bulat Okudzhava expresses the need for creating the reality by the subject of moral acts. He says that the fate of the universe - the fate of an ontic totality - depends on the decisions and choices of this subject, because, although the existence of the universe is being sustained by the non-anthropomorphic godhead, the same godhead is (almost) absent in the universe. The absence of the Infinite Divinity remains an ontological condition for the existence of finite beings which are placed within the space left by the Infinity as a result of an absolutely unknown and incomprehensible reason. ${ }^{25}$

25 "In the beginning, for unknowable reasons, the ground of being, or the Divine, chose to give itself over to the chance and risk and endless variety of becoming" (Jonas 4). 


\section{BIBLIOGRAPHY}

Berkovits, Eliezer. "Faith after the Holocaust". Essential Essays on Judaism. Ed. D. Hazony. Jerusalem: Shalem Press, 2002. P. 315-332.

Berkovits, Eliezer. God, Man and History. Ed. D. Hazony. Jerusalem: Shalem Press, 2004.

Baigell, Matthew. "Jewish-American Artists and the Holocaust: The Responses of Two Generations". In God's Name: Genocide and Religion in the Twentieth Century. Ed. O. Bartov, P. Mack. New York-Oxford: Berghahn Books, 2001. P. 342-349.

Buber, Martin. “Distance and Relation”. Martin Buber on Psychology and Psychotherapy: Essays, Letters, and Dialogue. Transl. Ronald Gregor Smith, Syracuse, NY, US: Syracuse University Press, 1999. P. 3-16.

Chosiński, Sebastian. „Zmarł Izaak Szwarc - legendarny radziecki kompozytor”. Web. 10.05.2016. <http:/ / esensja.stopklatka.pl/ film/publicystyka/tekst.html?id=8811>

Dmitriev, Andriei. "Proizrastanie mysli" [The Vegetative Period of Thought]. Samoilov, David. Izbrannoe [Collected Works]. Moskva: Knizhnyi Klub Knigovek, 2014. P. 5-12.

Elior, Rachel. "Tzimtzum: A Kabbalistic Approach to Creation". Shma: A Journal of Jewish Ideas. Web. 10.05.2016. <http://shma.com/2010/01/tzimtzum-a-kabbalistic-approach-to-creation/>

Fackenheim, Emil. To Mend the World: Foundation of Post-Holocaust Jewish Thought. Bloomington: Indiana University Press, 1994.

Fine, Lawrence. Physician of the Soul, Healer of the Cosmos: Isaac Luria and His Kabbalistic Fellowship. Stanford: Standford University Press, 2003.

Heschel, Abraham J. God in Search of Man: A Philosophy of Judaism. New York: Farrar, Strauss and Giroux, 1975.

Ivanova Vera, Manykin Mikhail. “Vladimir Vysotsky (1938-1980)”. Web. 10.06.2016. <http:/ /www.russia ic.com/people/general/v/122/>

Jonas, Hans. "A Concept of God after Auschwitz: A Jewish Voice". The Journal of Religion 67, No. 1 (Jan. 1987). P. 1-13.

Lévinas, Emmanuel. Totality and Infinity: An Essay on Exteriority. Transl. Alfonso Lingis. Pittsburgh: Duquesne University Press, 1969.

Levitanskii, Iurii. "Kazhdyi vybiraet dlia sebia" [Everyone chooses for himself]. Den' takoi-to [A usual day]. Moskva: Sovetskiy pisatel', 1976. P. 101.

Leerssen, Joep. "Imagology: History and method". Imagology: The Cultural Construction and Literary Representation of National Characters. A Critical Survey. Eds. M. Beller, J. Leerson. Amsterdam-New York: Rodopi, 2007. P. 17-32.

Matt, Daniel C. The Essential Kabbalah: The Heart of Jewish Mysticism. New York: Harper One, 1995.

Okuzdhava, Bulat, “O Volodie Vysotskom”. Web. 08.06.2015 (1). <http://www.kulichki.com/vv/ ovys/pesni.html>

Okudzhava, Bulat. "Pesenka o moiei zhizni". Web. 10.05.2015 (2). <http://www.bards.ru/archives/ part.php?id=10368>

Okudzhava, Bulat. Zamek nadziei ["The Castle of Hope”]. Kraków: Wydawnictwo Literackie, 1984.

Podgórzec, Zbigniew, red. Wysocki. Życie i twórczość. Warszawa: Wydawnictwo Współpraca, 1989.

Pushkova, Darya. "Prominent Russians: Bulat Okudzhava". Web. 10.05.2016. <http://russiapedia. rt.com/prominent-russians/music/bulat-okudzhava/> 
Scholem, Gershom. Major Trends in Jewish Mysticism. New York: Schocken Books, 1995.

Sikora, Tomasz. "Aliud valde - wokół idei Hebraizmu Oskara Goldberga" [Aliud valde-Around the Idea of Hebraism by Oskar Goldberg]. Oskar, Goldberg. Rzeczywistość Hebrajczyków. Transl. Tomasz Sikora. Kraków: Nomos, 2012.

Urban-Podolan, Aleksandra. Poezja Bułata Okudżawy. Między poetyka a interpretacją. Zielona Góra: Uniwersytet Zielonogórski, 2008.

Vlady, Marina. Wysocki, czyli przerwany lot. Transl. Kalina Szymanowska. Warszawa: Czytelnik, 1990.

Vysotskii, Vladimir. "Antisemity". Web. 30.04.2016. <http://www.kulichki.com/vv/pesni/zachem-mne-schitatsya-shpanoj.html> 